\title{
Melancholy of the Law
}

\author{
Przemyslaw Tacik $^{1}$ iD
}

Accepted: 6 September 2020 / Published online: 26 September 2020

(c) The Author(s) 2020

\begin{abstract}
The paper attempts to construct a theoretical account of what melancholy-in a psychoanalytical and cultural sense-may mean for jurisprudence. It argues that the map of relations and displacements between the object and the subject that is associated with melancholy in different psychoanalytical approaches can be fruitfully adopted for understanding of normativity. Based on a thorough re-reading of Freud's Trauer und Melancholie (Mourning and Melancholy), it suggests that there is an irremovable component of melancholy contained in the primordial act of separation of normativity from non-normative reality. This interpretation is confronted with Kelsen's Theory of Pure Law in order to analyse in which respect the momentum of self-sufficiency within normativity entails structures of melancholy. Kelsen's concept of 'effectiveness' is proposed as a key link which explains how melancholic withdrawal allows the law to interact with reality. Then the paper discusses Agamben's theory of applicability and of the state of exception to demonstrate the law's melancholic trap. Finally, the paper draws on Lacanian and post-Lacanian approaches to melancholy in order to investigate how melancholic momentum is inherent in the very structure of the law's validity.
\end{abstract}

Keywords Agamben · Applicability $\cdot$ Kelsen · Melancholy $\cdot$ Normativity · Psychoanalysis

\section{Introduction}

Can the law have its own specific form of melancholy, deeply engrained in the very structure of legality? Or, to venture an even more provocative thought, can this melancholy be a condition of possibility of norm-application? Is there something within the law that makes it melancholic? And, if the link between melancholy and law is something more than an accidental figure of speech, what can the former explain in the functioning of the latter?

Przemyslaw Tacik

przemyslaw.tacik@uj.edu.pl; przemyslaw.tacik@gmail.com

1 Jagiellonian University in Kraków, Kraków, Poland 
Melancholy and law are not words that often go together. It would be too figurative or too poetical, one might say, to couple them. If they are juxtaposed, as in Jan Klabbers' recent European Society of International Law contribution (Klabbers 2018), it is usually for the purpose of highlighting the author's dissatisfaction with the direction that the law or legal scholarship have taken recently; melancholy, there, is nothing more than a term for nostalgic reflection on the lost good times. Alternatively, the combination of the two terms might connote a legal professional's depression (Silver 2011). There are also some more substantial theoretical accounts of their possible constellations, although not direct ones: melancholy and the law are mediated by a subject that entertains relations with both. In this perspective, Bernard Edelman offered a brilliant reading of Kant's theory of author's rights as a protection against an individual's melancholic folly (Edelman 2007, pp. 59-82). Here, however, the law has little to do with melancholy itself apart from being a bulwark against its colonisation of a subject. Peter Goodrich in his unfailing ingenuity proposed an account of 'melancholegalism', an endemic condition of lawyers, 'the parlous and obscure desire of souls lost in the law' (Goodrich 2016, p. 201). Yet in this concept melancholy and the law are once again linked by a psychological nexus provided by a particular subject. Indeed, the law can protect a subject from herself or, contrariwise, plunge her into the abyss of saturnine devotion to the corpus iuris. But if melancholy provides an unsurpassed distant gaze of what-is-already-dead, should not the law itself-precisely in its intransigence and ghastly torpor-be its subject?

Since Robert Burton's classic work on melancholy (Burton 1927/1621), it has become one of the most productive terms in the humanities that exploded with reinventions and transformations after Freud's classic article 'Mourning and Melancholy' (Freud 1957; Radden 2000, pp. 4, 28); it would seem surprising if it had no true adaptation in legal studies. In modernity it lost its purely psychological dimension and expanded to explain the status of things, nature and the world itself. The structure of relations that melancholy connotes nowadays-as a term re-appropriated by the humanities - is stunningly adaptable to legality. Moreover, the application of psychoanalytical terms to jurisprudence has already a long tradition in critical legal thinking (Goodrich and Carlson 1998). This paper aims to enter this uncharted territory and bring the relationship between the law and melancholy to a properly conceptual level, beyond any individual psychology.

\section{Trap of the Law}

Before we proceed to a detailed analysis of Freudian understandings of melancholy, let us begin with a post-psychoanalytical working definition: melancholy is a displacement in the economy of the subject in relation to the object (cf. Freud 1957, p. 249). In the post-Lacanian perspective the normalised concept of the object is developed into the notion of the Thing (Lacan 1986, pp. 95-122; Kristeva 1992, pp. 13-15). In both cases melancholy transforms the subject's bond with the position of the object as a response to some traumatic deforming force. This displacement distorts equilibrium between the subject and the object, thrusting the latter into an imaginary position of pre-determined dependence on the subject. It is only in this 
way that the subject can compensate for its structural deficiency originating in the primordial trauma.

The first source which allows us to link this understanding of melancholy with the law is ancient. The Tanakh (the Hebrew Bible) has preserved a revelatory story on the dependence-based melancholic structure of the law. The second book of Kings contains a narrative on Josiah, a king of Judah reigning in the years 640-609 BCE, who undertook a profound politico-religious reform and reinstated fiercely monotheistic Judaism as a foundation of the state. Chapter 22 of the second book of Kings (Kings 2017) describes him in retrospect as a righteous ruler full of fear of God:

Josiah was eight years old when he began to reign; and he reigned thirty and one years in Jerusalem [...]. And he did that which was right in the eyes of the LORD, and walked in all the way of David his father, and turned not aside to the right hand or to the left. (2 Kings 22: 1-2)

With unsurpassed succinctness the Tanakh proceeds to the central event in the life of Josiah (Henige 2007, p. 8). The king orders a refurbishment of the Temple. On this occasion Hilkiah, the high priest, makes a fearful discovery:

And Hilkiah the high priest said unto Shaphan the scribe: 'I have found the book of the Law in the house of the LORD.' And Hilkiah delivered the book to Shaphan, and he read it. And Shaphan the scribe came to the king, and brought back word unto the king, and said: 'Thy servants have poured out the money that was found in the house, and have delivered it into the hand of the workmen that have the oversight of the house of the LORD.' And Shaphan the scribe told the king, saying: 'Hilkiah the priest hath delivered me a book.' And Shaphan read it before the king. And it came to pass, when the king had heard the words of the book of the Law, that he rent his clothes. (2 Kings 22: 8-11)

Suddenly, after years of oblivion, the book of the Law is discovered. According to the story, throughout this time it had not been known and, as a result, not obeyed. The Jewish Law at that time paid little attention to the question of error or unawareness of its subjects. Therefore even those who acted against the Law without the consciousness of it were objectively at guilt. Hence the only thing that was left for the king was to tear his clothes, more in an act of prostration rather than repentance. Josiah sends his emissaries, the high priest among them, to inquire the Lord, as he fears the worst retaliation for years of neglecting the Law:

Go ye, inquire of the LORD for me, and for the people, and for all Judah, concerning the words of this book that is found; for great is the wrath of the LORD that is kindled against us, because our fathers have not hearkened unto the words of this book, to do according unto all that which is written concerning us. (2 Kings 22: 13)

The discovery of the book of the Law not only actualises his guilt at the irreparable negligence of the Torah, but also transforms the perception of what was happening to Judah: all misfortunes suddenly appeared in the light of the Law as the Lord's wrath for ignoring the norms. Just with one contingent discovery the Law 
emerges, producing guilt and changing the meaning of the past and the present. Inquired via a prophetess, God responds in defence of the violated Law:

Behold, I will bring evil upon this place, and upon the inhabitants thereof, even all the words of the book which the king of Judah hath read; because they have forsaken $\mathrm{Me}$, and have offered unto other gods, that they might provoke Me with all the work of their hands; therefore My wrath shall be kindled against this place, and it shall not be quenched. (2 Kings 23: 16-17)

Josiah himself obtained a special grace; due to his loyalty to the Lord, he was promised to die early enough not to see the calamity of Judah. Notwithstanding God's answer, the king attempted to make up for the past sins. Chapter 23 of the second book of Kings provides a detailed list of his anger-imbued actions: Josiah renewed the covenant with God, promising to keep the Law; he began a massive anti-idolatrous campaign which involved destroying pagan vessels and statues, killing pagan priests, defiling places of worship and eradicating any signs of cults other than Judaism. He destroyed the altars of past kings who misguided Israel, and burned bones of the idolatrous. Finally, he commanded to observe the Passover, which had not been celebrated during the period of oblivion of the Law.

The whole story is concluded with a Job-like paradoxical denouement. First the Tanakh expresses outright appreciation of Josiah's actions:

And like unto him was there no king before him, that turned to the LORD with all his heart, and with all his soul, and with all his might, according to all the law of Moses; neither after him arose there any like him. (2 Kings 23: 25)

But the Tanakh then declares all his deeds fundamentally futile in relation to the violation of the Law:

Notwithstanding the LORD turned not from the fierceness of His great wrath, wherewith His anger was kindled against Judah, because of all the provocations wherewith Manasseh had provoked Him. (2 Kings 23: 26)

The judgment was pronounced as structurally irrevocable. No repentance could make up for violation of the Law. Its norms, apparently given once and for all, could not make any allowances for the facts. This stunning intransigence is attributed to the unabating wrath of God-but is there not something in the very position of the Law that makes it structurally intransigent?

This story still puzzles biblical researchers. The book of the Law (ספר התורה) discovered in the Temple is widely believed to be Deuteronomy (Stott 2005, p. 155; Henige 2007, p. 3). Nonetheless, it is hardly sensible to take the story at face value; much more probably the second book of Kings provides a retroactive, pseudo-historical narrative on the centralisation of cult and expansion of fierce Jewish monotheism. Discontinuities in 2 Kings might attest to this interpretation (Janzen 2013, p. 350). If so, then the 'discovery' of the Book would be a distorted explanation of the composition of Deuteronomy, necessary for the purpose of assuring coherence in the history of Israel after the exile (Noth 
1960, pp. 274-277; Henige 2007, p. 13) or aiming at rhetorical endorsement of reforms in the times of Josiah (Conrad 1992, pp. 45-59). The physical existence of 'the Book' and its 'discovery' are therefore highly dubitable (Stott 2005, p. 167; Davies 2005, p. 70), although some researchers still believe them not to be implausible (Cogan 1998, p. 346; Henige 2007, p. 3). Scarcity of reliable sources allows the imagination to produce almost all interpretations within the logical limits determined by the story's plot (Henige 2007, pp. 6-15).

No matter which option is actually true, the story conveys a thought-provoking vision of the law. Firstly, the law, once established, has been always already here. No matter if respected or not, it awaits the subjects as a pre-determined trap. In this respect the two interpretative options of the story - that the Book was actually obliterated and then rediscovered or, alternatively, that the story provides a mythical grounding of the establishment of the law-are indifferentiable. Even if the law was composed at that time, it is posited as having been in existence before. The emerging law produces its own history. From the point of this history the subjects of the law are always in delay.

Secondly, there is an irreducible component of timelessness in the law. Obviously, the second book of Kings refers to religious law, in itself conceived of as eternal. But given that this law was also actually codified, we might see its inherent eternity only as extreme intensification of the law's usual timelessness. In the realm of the law, until its amendment or deposition, time does not flow. The book of the Law might be buried for centuries; when unearthed, it instantly rivets the present to the moment when the norms were established.

Thirdly, violation of the law is, ultimately, irreparable. This is the gist of the story: if a norm of the law is breached, it does not affect the law no matter how long the violation lasts. Such a 'biblical hard-line Kelsenism' brings the norm/fact dualism to its end. The law exists in its own, immutable temporality, which is never affected by its ineffectiveness. There can be no desuetudo of which to conceive. Violation is as eternal as the law itself, and such is the punishment. The only condition is that the law is discovered. Then it returns to reality with surprising effectiveness because it not only achieves what it prescribes, but also perpetuates its reign by production of indelible guilt.

Finally, violation appears and entails consequences only after the law is unearthed. As long as the book of the Law remained isolated from the eyes of its subjects, not only guilt was absent, but also lamentable effects of transgression did not see the daylight. But as soon as the law was revealed, irreparable guilt for the past emerged and calamities began to ravage Israel. It is transparency of the law that makes it work, although even while concealed it preserves its potential to re-emerge and demand settling the score. Within the law nothing is ever forgotten, but, at best, only temporarily suspended.

Let us now try to bring these conclusions closer to the psychoanalytical field, to which melancholy belongs. If the violation of the law is seen as a loss, then there might be two general strategies of response from the part of the law. The first one is mourning: the law makes its peace with the breach, negotiating a third way between total disrespect of its norms and the already impossible norm-application. 'Mourning' in the law would mean making allowances for the fact in a pragmatic, 
reality-centred manner. But there is also a second strategy: melancholy. In a Freudian approach, melancholy consists in staunch refusal to acknowledge the loss. The 'melancholic' law perpetuates it, making the violation eternal and irreparable. God's personhood behind the law adds to it even more psychoanalytic flavour: through its words the law speaks itself in its inconsolable perpetuation of the breach. The subjects of the law are thrown into the position of eternal dependence and guilt. In this lies the crux of Josiah's story and the key to exploring the link between the law and melancholy.

\section{Psychoanalytic Account of Melancholy and the Force of the Law}

Let us now return to Freud's understanding of melancholy in more detail in order to grasp its consequences for the law.

Famously, Freud contrasts mourning and melancholy as two reactions to a loss of an object, which may be of multifarious types, from a beloved person to an abstract value, such as liberty or an ideal (1957, pp. 243, 247). Mourning has its structurally embedded end: it involves gradual recognition of irrevocability of the loss, which leads to withdrawal of libidinal relations with the object and healing of the subject (Freud 1957, pp. 244-245). On the contrary, melancholy perpetualises itself. It is no longer about the loss of the object: the loss engulfs the very relationship between the object and the subject. In melancholy, the subject is ultimately impoverished and wallows in self-abasement (Freud 1957, p. 246).

Here Freud adds a crucial twist: the subject 'must surely be right in some way and be describing something that is as it seems to him to be' $(1957$, p. 246). The negative disposition of the subject towards itself has a real, although displaced cause. By accusing and deprecating itself, the subject in fact targets the object of its former strong cathexis (Freud 1957, p. 248). Referring to the patients of his practice, Freud remarks: 'All this is possible only because the reactions expressed in their behaviour still proceed from a mental constellation of revolt, which has then, by a certain process, passed over into the crushed state of melancholia' (1957, p. 248).

Proceeding from psychology of individuals towards a more general perspective, it might be noticed that Freudian understanding of melancholy involves a permanent struggle of the subject with a foreign intrusion by which it is inhabited. On the one hand, this intrusion is constantly reviled and revolted against, which only fuels the subject's self-loathing. On the other hand, the subject seems irretrievably possessed by the shadow of the object in itself. Due to its primordial unacceptance of the loss, it is unable to get rid of this haunting spectre to the point that it painfully tolerates its own splitting. In anticipation of the adaptation of melancholy to the context of legality, it seems crucial to notice that Freud understands this condition to produce within the subject a hollow space that mimics the real object. Melancholy is a game of shadows: the object, lost in reality, is preserved as a spectre within the subject-with all the interplay of love and hate moving into the subject.

As a result, there is a displaced core of truth in each statement tainted by melancholy. As Freud notices regarding his melancholic patients, "[t]hey are not ashamed and do not hide themselves, since everything derogatory that they say 
about themselves is at bottom said about someone else'; therefore, 'they make the greatest nuisance of themselves, and always seem as though they felt slighted and had been treated with great injustice' (Freud 1957, p. 248). The melancholic position evinces the aura of superiority over the object, albeit distorted by the change of vector of contempt. The structure of melancholy makes the subject primordially elevated in relation to the object: the latter is always thrown into the condition of guilt stemming from some injustice that seems to have been committed in regard to the subject. Whenever the subject deprecates itself, in fact it is the object to which the deprecation refers. As a result of this displacement, melancholy is capable of unleashing unprecedented potential of sadism and hatred (Freud 1957, pp. 251-252).

Freudian melancholy is, in a sense, based on a deliberate choice of the subject. Instead of confronting the loss in reality, a melancholic position establishes 'an identification of the ego with the abandoned object. Thus the shadow of the object fell upon the ego, and the latter could henceforth be judged by a special agency, as though it were an object, the forsaken object' (Freud 1957, p. 249). In melancholy the subject brings the relationship with the object to its own ground by identifying with it and splitting itself. Yet the victory is partial: the subject now struggles with a tendency to get rid of the incorporated subject which disturbs it, even if, at the same time, it wants to keep the object in, in order to dominate over it (Freud 1957, pp. 256-257). Melancholy entails profound ambivalence and permanent structural tension over the relationship with reality and the object that was part of it.

How could this theoretical account of melancholy be adapted to legal theory? As I noticed previously, violation of the law is, within the law itself, a properly irreparable act which can never be erased from the registry. At the same time it touches upon the mysterious locus in which the law faces reality, the same locus which-as I will demonstrate later-Agamben interrogates in his work on suspension of the law. Perhaps then the intransigence of the law, depicted so tellingly by the Book of Kings, seems to be structurally embedded in the detachment from reality that founds normativity of the law. Violation of the law, if seen as a loss, only repeats the primordial loss on which the whole edifice of the law is built.

From this perspective the relation between the law and reality-to which the law relates, among others, through the concepts of validity and application-could be seen as a structurally disturbed melancholic displacement. Perhaps the law emerges by absorbing reality into itself through identification. Within this 'melancholic vision of the law', reality is an ambivalent incorporated object that the law simultaneously aims to withhold in itself and get rid of. When facing the true reality, for example in the process of application, the law relates to it via the redoubling that it performs: each relation to reality is mediated through the ideal reality within the law itself. The law would be thus afflicted by fundamental ambivalence between the temptation to be self-sufficient and the need to be applied and effective. It wants simultaneously to determine reality as something external, and absorb it fully into itself. Following Nicolas Abraham's and Maria Torok's terminology (1987, p. 266), it can be noticed that the law turns reality into its own crypt in which it is preserved for perpetuity. 
Accordingly, the law is as intransigent as a melancholic subject. Its object is in the position of permanent inadequacy. Each element of the relation between the law and reality is scrutinised in the light of its discrepancy with the normative ideal. In its melancholic position, the law never forgets or pardons: the registry of violations only mounts.

\section{The Portrait of Hans Kelsen as a Legal Scholar of Melancholy}

This melancholic ambivalence of the law is clearly discernible in one of the foundational works of twentieth-century legal theory, Hans Kelsen's Pure Theory of Law. As I will attempt to demonstrate, the paradigm it inaugurated-focused on analysing pure normativity - is mired in the melancholic position that the law may assume. In his balky struggle to found legal theory on the autonomy of normativity, Kelsen enters the area where melancholy of the law is most acutely palpable.

Let us begin by noticing that when he develops his vision of normativity, Kelsen clumsily confronts the problem of the relationship between the law and reality. Pure Theory of Law begins with the well-known Kant-inspired declaration of fundamental difference between ought and is, the norm and the fact (Kelsen 2005, pp. 5-6). 'This dualism', Kelsen immediately adds, 'does not mean, however, that there is no relationship between is and ought' (2005, p. 6). The law cannot be admitted to hover in the air as the untouchable Laputa island from Jonathan Swift's Gulliver; it needs to relate to reality. Yet precisely in this relation the law reveals its melancholic redoubling. According to Kelsen, the law relates to reality just as the behaviour stipulated by a norm relates to the actual behaviour $(2005$, p. 6$)$. In other words, this relation is already determined by the normative framework; the norm acts as 'a scheme of interpretation' (Kelsen 2005, p. 3). The law is in relationship to reality through a normatively determined spectre reality that it itself produces.

The key to this redoubling is nothing less than the process in which a subjective norm becomes objectivised by finding support in the Grundnorm, 'a presupposition establishing the objective validity of the norms of a moral or a legal order' (Kelsen 2005 , p. 8). Without going here into endless discussions on the actual meaning of Kelsen's Grundnorm (see Bindreiter 2003; Raz 1974), it should be noticed that the process of objectivisation which turns individual will into a general norm is, psychoanalytically speaking, tantamount to the primordial melancholic dispossession of reality. By objectivising itself, a particular will is elevated to the rank of parallel, universally recognisable reality. It passes from the realm of being to the realm of validity; and it is validity that becomes 'the specific existence of a norm' (Kelsen 2005 , p. 10). The emergence of the Grundnorm is a momentary act in which perspectives are switched, as if in Žižekean 'parallax view' (Žižek 2009). Just as the appearance of melancholy is not an act within reality, but an act that displaces the relationship to it, so is Grundnorm-based normativity a disturbance in the existence of what is real.

It is now that the melancholic ambivalence of the law comes to the fore. Kelsen addresses the relationship between validity and effectiveness of norms by taking a false middle path between the two, but he does it in order to demonstrate his 
willingness to reach a compromise with his staunch Kantianism. The norm exists regardless of whether it is followed; it always precedes its application, so reality is put in the position of primordial dependence on it (Kelsen 2005, p. 11). Yet at the same time Kelsen is ready to acknowledge that '[a] general legal norm is regarded as valid only if the human behaviour that is regulated by it actually conforms with it, at least to some degree' (2005, p. 11). An eye well-versed in deconstruction will immediately identify this 'some degree' as a crucial locus of aporia. 'A minimum of effectiveness is a condition of validity', Kelsen adds (Kelsen, 2005, p. 11), noticing at the same time that the norm must preserve the possibility of being violated, because a norm which acts like a law of nature is 'senseless' (2005, p. 11).

Melancholy is not an entire world in itself: it is relating to the world through its suspension and re-doubling. For this reason there always should be some link between the melancholic spectral reality and external reality, otherwise the redoubling is senseless. It is a fundamental error to see melancholy as a passive defence, or even a complete withdrawal from the world: melancholy wants to be active in relation to reality, but with other means. In Freud's theory, the principal reason for the ego's identification with the object is not a renunciation of it: that would be actually a sign of healing. A melancholic ego absorbs the object precisely for the fact of not being capable to let it go. It is not able to relate to it as something entirely external which needs to be respected in its separation and abandoned if necessary. What is manifest in melancholy is precisely not abandonment of reality, but too strong a relation to it which cannot be overcome otherwise than through forced absorption of it into the subject. The 'depressive position', to use Melanie Klein's term (Klein 1975, pp. 13-15), would therefore condition the very link between the law and reality.

Kelsen's account of normativity reveals the law's obsession with reality. In his vision the law is both separate from reality, unshakeable in its normative self-sufficiency, and dependent on it to the point of losing its very existence-that is, validity-if it does not prove effective. In order to navigate between the Scylla of validity and Charybdis of effectiveness Kelsen proposes a seemingly compromise solution:

Just as the norm [...] as the meaning of an act is not identical with the act [...], in the same way is the validity of a legal norm not identical with its effectiveness; the effectiveness of a legal order as a whole and the effectiveness of a single legal norm are-just as the norm-creating act-the condition for the validity; effectiveness is the condition in the sense that a legal order as a whole, and a single legal norm, can no longer be regarded as valid when they cease to be effective. (Kelsen 2005, pp. 211-212)

In other words, normativity is born only from the establishment of the Grundnorm, that is - the law's absorption of reality and identification with it. But in order to survive, norms need to be recognised as valid, for which they require effectiveness (see also Kelsen 1992, p. 60). In the same manner melancholy arises from a primordial displacement in relation to the subject, but will burn out if it does not bring gains by entangling the subject. Normativity, just like melancholy, becomes useless when turned into ultimate passivity dissociated from reality to which it relates. Kelsen's 'compromise' is not a sign of weakness, let alone a token of common sense in taking 
a step back from most radical Kantianism: it is a crucial bolt that allows normativity to engage in reality through redoubling.

In its melancholic dimension, normativity would then be close to the modern understanding of melancholy. Dürer's famous engraving Melencolia I (1514), which portrays it allegorically as a reflexive woman surrounded by scientific instruments, exposes the ambivalence of scientific cognition explored by Aby Warburg and his disciples, Raymond Klibansky, Erwin Panofsky and Fritz Saxl (Traverso 2016, pp. 41-42). Melancholy is both a method of conquering the world with the scientific gaze and the exhausted disappointment stemming from the inability to grasp it fully. 'It is a confession and an expression of Faust's "insuperable ignorance", as Klibansky, Panofsky and Saxl put it (1979, p. 365). Melancholy is therefore far from being passive: it rather attempts to win over reality through reflection and self-reflection while recognising the limits of cognition.

In his 'pure theory of law' Kelsen inadvertently reveals the melancholic underpinning of the law. It is therefore of little surprise that some of the influential criticisms targeted at his thought re-enact the classic anti-melancholic positions. The famous interwar polemics between him and Carl Schmitt embody the conflict between melancholic 'withdrawn activeness' and glorification of vitality and force of real life. Schmitt, expounding his concept of exception in Political Theology, famously claims that

The exception is more interesting than the rule. The rule proves nothing; the exception proves everything. It confirms not only the rule but also its existence, which derives only from the exception. In the exception the power of real life breaks through the crust of a mechanism that has become torpid with repetition. (Schmitt 1985, p. 15)

Schmitt's vitality, however, is not the expression of primordial or 'authentic' life. It only arises out of the refusal of the melancholic position of the law and, in this sense, has a reactionary character despite its calls for 'the power of real life'. This is clearly recognisable from the negative reference to the 'crust' of death-stricken normativity that he wants to overcome. For Schmitt, (Kelsenian) normativity is 'torpid with repetition', just as melancholic patients from Freud's portrayal. Nonetheless, what Schmitt proposes as a cure is not abandonment of melancholy, but rather a kind of a 'normative mania' in which the melancholic structure is preserved at its bottom, yet suspended for the sake of real life.

In other words, the debate between Kelsen and Schmitt (Cercel 2018, pp. 18-45) - if read in the light of melancholy of the law-does not have its central axis in the question whether the law is melancholic or not. Both scholars avow it implicitly: Kelsen when building the tower of self-sufficient normativity only to acquiesce its necessary link to reality, and Schmitt when he summons the power of real life against normativity mired in undead repetition. They differ rather in the approach to how the melancholy-stricken law should be approached. Kelsen seems to accept melancholy of the law as the fundamental framework of its influence on reality. The redoubling that the law performs on it is a necessary element of the reign-throughabsorption strategy. Schmitt is not, as it could be expected, an adherent of normative 'mourning' against melancholy. What he attempts to unleash are the powers inherent 
in normativity, but covered with its melancholic structure. His quest of the sovereign grip embedded in the law through the device of exception is tantamount to a gesture of re-appropriating melancholy by seeking its primordial act of separation from reality.

\section{Melancholy of the Inner Suspension of the Law}

The Schmittian exception would be therefore not a point in which life breaks with the melancholic torpidity of the law, but rather a privileged site in which melancholy of the law becomes visible and requires an adequate response. Giorgio Agamben's philosophy of the law provides here a telling example: when stripped of the Fascistlike celebration of life and reality, the exception becomes the crucial aspect of normativity in which the relationship between the law and the fact is laid bare. What happens at this site is the confrontation of the norm and being, mediated by the inherent suspensibility of the law. Agamben demonstrates that the law does not simply apply to reality, but each time overcomes its primordial melancholic withdrawal in order to reach being. The result, as once suggested by Wittgenstein in Kripke's reinterpretation (Kripke 1982), is undeterminable in the last instance, because the leap from normativity to being is in itself not guided by rules.

Let us then look briefly at Agamben's take on melancholy of the law which is implicit in his theory of exception. One of his canonical definitions of exception accentuates its relation to suspension of norms:

The exception is a kind of exclusion. What is excluded from the general rule is an individual case. But the most proper characteristic of the exception is that what is excluded in it is not, on account of being excluded, absolutely without relation to the rule. On the contrary, what is excluded in the exception maintains itself in relation to the rule in the form of the rule's suspension. The rule applies to the exception in no longer applying, in withdrawing from it. The state of exception is thus not the chaos that precedes order but rather the situation that results from its suspension. (Agamben 2005a, p. 39)

For Agamben, suspension-revealed in the exception-is inherent in the law, but not exclusive to it. On the contrary, with a generous metaphysical generalisation Agamben presents the suspension of action or applicability not only as the propensity of language, but even as part and parcel of being human. In Creazione e anarchia Agamben notices that 'the human is the living being that exists eminently in the dimension of potential, of being-able-to and being-able-not-to' [del potere e del poter-non]' (Agamben 2019, p. 20; 2017a, p. 37). The ability to 'not do', to withdraw one's action and preserve it in the state of potency is characteristic of an animal possessed by language. This potency is embodied in a maxim referring to God's revelation to Moses in the burning, but non-consuming fire: 'ignis ardens non comburens' (Agamben 2019, p. 23). Potency is not only capable of action, it is pregnant with it, but reveals itself when the action is suspended.

Agamben develops a special term in order to grasp the language (and, as corollaries, art and techne) that becomes deactivated in its potency: inoperativity 
(inoperosità) [2019, p. 27; 2017a, p. 47; 2017b, p. 139; 2005b, pp. 95-99; 2014, pp. $130-131$, pp. 350-351]. Accordingly, poetry is the celebration of the inoperativity of language: 'an operation in language that deactivates and renders inoperative its communicative and informative functions in order to open them to a new possible use' (Agamben 2019, p. 27).

The inoperativity dormant in language is visible also in law. In Agambenian portrayal it is not the suspension of the law that demands explication; on the contrary, the law is based on suspension and, in fact, it is its applicability that remains a puzzling enigma. In this staunch commitment to melancholic normativity Agamben radicalises even the Kelsenian dualism of the law and the fact:

while morphologically identical to the verbal expression of the indicative, the command [...] does not manifest the being or non-being of something, it does not describe or deny a state of things, and without being for this reason false, it does not refer to anything existing in the world. It is necessary to avoid with all due caution the equivocation according to which the meaning of the imperative would consist in the act of its execution. ... We must therefore admit unreservedly that nothing, in the world as it is, corresponds to the imperative. (Agamben 2019, pp. 50-51)

Consequently, Agamben follows Schmitt to the roots of primordial separation from reality that builds up normativity, but does not find there any "power of life'. At the bottom of normativity there is nothing but inoperativity which stems from the melancholic absorption of reality into the law. Agamben offers a thorough reappraisal of Kelsen in which duality between Sein and Sollen is properly inexplicable and based on a more fundamental rift between two ontologies, the ontology of being [essere] and of obligation [dover-essere] (Agamben 2012, pp. $140-143)$. When this rift is grasped in the most radical way, normativity discloses its insurmountable solitude.

If so, how can the law be applied at all? If interpreted radically enough, Agamben seems to draw the ultimate conclusions from Wittgenstein's reflection on rules (Wittgenstein 1974, pp. 74-87). 'Proper application' of the law does not exist:

in the case of law, the application of a norm is in no way contained within the norm and cannot be derived from it; otherwise, there would have been no need to create the grand edifice of trial law. Just as between language and world, so between the norm and its application there is no internal nexus that allows one to be derived immediately from the other. (Agamben 2005a, p. 40)

Naturally, this nexus is, in Agamben's theory, safeguarded by the state of exception. Accordingly, each act of applying the law is twofold. The law bifurcates into the force-of-law, which hovers spectrally over the 'application act', and the exception, which assures that some act is effectively produced. On the one hand, the law may somehow correspond to an executed act (cf. Agamben 2019, p. 50) and, in this sense, pass off for a rule that 'was applied'. But even if this act corresponds perfectly to the rule, the melancholic inertia of the law-its self-ensconcement in the normative-is preserved. It is for the essential incompatibility of the law with 
the world that each act of its 'application' leaves it unsatisfied. In other words, there is a melancholic excess not only in violation of the law, but even its purportedly 'successful' application. What Agamben names 'force-of-law' (Agamben 2005a, p. 40) is nothing but the law crystallised in its melancholic position.

After the rule is 'applied', there is still some remainder of normativity which is never consumed by the act. Therefore perceiving the law from the perspective of its application or effectiveness is defective as long as we focus just on the real act which was triggered by it. It does not mean, however, that effectiveness or relation to the world is inconsequential in the law; Kelsen himself desperately defended this element of normativity. But effectiveness needs to be understood just as mere juxtaposition of ought and is, a kind of après-coup injustice done to the law from an abstract position. To say that a norm was effective is tantamount to telling a melancholic in despair that at least she managed to get up in the morning precisely at the moment when the abyss of the coming day is yawning before her. Meanwhile, between the law and the fact there is the irreducible zone of melancholy of the law. Even effective norms cast the black melancholic light upon their 'acts'. In this sense, the law can never square with the facts without losing its normative character and the melancholic residue it produces.

It is for this reason that Agamben is pushed to seek perspectives in which the law would be 'consumed' not through acting according to its injunctions, but in the recognition of its inner suspendability. His work on monastic life, Altissima povertà, develops an interpretation of lectio continua, a practice of liturgical reading of the law. Agamben argues that in lectio continua

The text of the rule is thus not only a text in which the distinction between writing and reading tends to become blurred, but also one in which writing and life, being and living become properly indiscernible in the form of total liturgicization of life and a vivification of liturgy that is just as entire. (Agamben 2013, p. 82)

Thus the whole 'redemptive' dimension of Agamben's work, which aims at loosening the ontology of injunction, may be interpreted as passivisation of the law within its melancholic residue. Analogically, the messianic elements, present especially in $I l$ tempo che resta, are based on the assumption that the Messiah's acts render the law inoperative: '[m]essianic katargēsis does not merely abolish; it preserves and brings to fulfilment' (Agamben 2005b, p. 99). But this fulfilment does not bring a new quality to the law, it rather aims to recuperate the dimension of inoperativity deeply imbedded in the very construction of normativity. Contemplative inoperativity, hailed as a redemptive path (Agamben 2014, pp. 350-351), would therefore be nothing but allowing oneself to be mired in melancholy. And that, notoriously, opens up a thousand gates to the cognoscenti but appears just as a multiplied illusion to all the others.

Ultimately, Agamben's path would be the utter triumph of melancholy of the law. As we saw in Kelsen, the melancholic construction of the law appears precisely in its contact with reality: apparent withdrawal did not have for its objective to abandon reality, but to dominate it by the use of re-doubling. Yet in Agamben melancholy turns into the final victory of the law. Fixed in its inoperativity, it no longer needs to be applied. The melancholic obstacle in relations between ought and is disappears, 
thereby opening up the perspective of eternal life within the realm of melancholy which finally engulfed reality without any remainder. Normativity no longer needs to be disturbed by the painstaking process of application: it now fulfils itself by being studied.

\section{Lacanian Icing on the Cake}

Lacanian psychoanalysis would be more eager to link the law either with the establishment of the Symbolic and its (non-)correlate, the Real, or with the sinthome (Murray 2005)—rather than to analyse the law's melancholic position. But the holy trinity of Lacan's examples for the intransigence of the law, Antigone (Lacan 1986, pp. 295-327), Kant and Sade (Lacan 1999, pp. 243-269; Lacan 1986, pp. 95-101, pp. 222-233; Lacan 1975, pp. 80-84; Zupančič 2000), reveal the intriguingly irremovable melancholic residue within the entanglement of the Symbolic and the Real.

First, the risk of 'legal radicalisation' understood as the law's swerving out of the control exercised by 'non-normative reality' remains an irremovable possibility within normativity. It is a one-way path of temptation: once adopted, it leads directly to Kant's allegedly 'inhumane' praise of veracity for all costs, including life (Kant 1993; Varden 2010). This temptation can never be tamed otherwise than by a reference to 'common sense' which acts as a corrective mechanism for normativity. Yet the paradox consists in the fact that within normativity there is no such mechanism.

Second, 'effectiveness' remains a fetish that allows the law to break with its dangerous normative self-sufficiency. But as evidenced by Kelsen, it is always an incoherent, begrudging compromise than cannot be well expounded theoretically. When 'effectiveness' comes up in legal reasoning it is as if a blind spot was reached: persuasiveness of arguments dissipates and is replaced with classic rhetorical gestures from the state of exception repertoire: 'it must be done anyway', 'let's have common sense' or 'it cannot go on like this'. Law should be effective, otherwise why should we have law? The problem is - as demonstrated by Lacan's Antigone-that by establishing normativity we unleash forces much more powerful than the alleged reality itself; at the same time, they are paralysed with melancholy to which only Agamben's calls for studying the law can do justice.

If effectiveness is understood as the law's capability of influencing 'non-normative reality', than this reality itself is a legal construct that acts as a interrupter within normativity's proneness to melancholic self-enclosure. What Kelsen describes as an already legally pre-prepared reality that the law applies to would therefore be just the fuse that the law uses to protect itself against the short circuit of normative melancholy. It is applicability as imagined within the law. But it is precisely for this reason, through action-in-inaction, that the melancholy of the law is part and parcel of its reign. And perhaps this is the proper sense of Derrida's otherwise oversimplistic view of the law's foundation only upon itself (1994, p. 34).

It might seem absurd and weirdly sentimental to follow the law in its mourning of a violation. But within normativity there is no obstacle to interpreting the following description of a melancholic by Kristeva to the law as such: 
Ever since that archaic attachment the depressed person has the impression of having been deprived of an unnameable, supreme good, of something unrepresentable, that perhaps only devouring might represent, or an invocation might point out, but no word could signify. Consequently, for such a person, no erotic object could replace the irreplaceable perception of a place or preobject confining the libido or severing the bonds of desire. Knowingly disinherited of the Thing, the depressed person wanders in pursuit of continuously disappointing adventures and loves; or else retreats, disconsolate and aphasic, alone with the unnamed Thing. (Kristeva 1992, p. 13)

\section{Conclusions}

Melancholy is an indispensable shadow of the very foundation of normativity. If the law emerges through re-doubling of reality and identification with its spectral, normatively reconstituted counterpart, it cannot forgo a melancholic disposition. The eternity of the inner realm of the law, so well discernible in Josiah's story, is a gain for which the law pays with a melancholic loss. But through this loss it reigns over its subjects who find themselves in the position of unsurpassable belatedness. The law is never lost; it may be at best obliviated. On the law's own ground, one can never win with it. Just as discussions with a melancholic may not be technically won, but only circumnavigated, so the law can be violated, but never appeased. In such a situation the law goes underground and turns reality into a realm of oblivion built upon the menacing possibility of rediscovering the breached norm. The more intransigent the law is, the more its reign over reality resembles Abraham's and Torok's account of melancholics who denigrate themselves in order to receive extolment from their object and demonstrate pride drawn from its misery (1987, p. 274).

Melancholy of the law is an uncomfortable quality. Experienced, tacitly or explicitly, both by legal scholars and practitioners, it is usually either muffled by referring to the abyssal polysemy of interpretation or jumped over with expeditious application of legal measures in the spirit of the state of exception. But the structural ineffectiveness of the law is an elephant in the room. The law revealed in its melancholic position displays similarly embarrassing features as a depressive patient: it is selfcentred, inert as a block of matter, imbued with morbid indifference to life. Just as a melancholic who believes everything to be lost in order not to suffer from a real loss, so does the law protect its vulnerability against reality. The eternity that opens up in the intransigence of normativity-making all violations irredeemable-renders the law unassailable on its own ground. Thus the menace of melancholy hovers over the law's applicability as its inner irremovable correlate.

'There is no greater cause of melancholy than idleness, no better cure than business', Robert Burton once claimed with his frivolous optimism (1927, p. 16). Indeed, the law arises from the idleness that elevates normativity above reality. But business, or rather application, is to the law nothing but a palliative. 
Acknowledgements The author would like to thank anonymous reviewers for thought-provoking references

\section{Compliance with Ethical Standard}

Conflict of interest The author declares that he has no conflict of interest.

Open Access This article is licensed under a Creative Commons Attribution 4.0 International License, which permits use, sharing, adaptation, distribution and reproduction in any medium or format, as long as you give appropriate credit to the original author(s) and the source, provide a link to the Creative Commons licence, and indicate if changes were made. The images or other third party material in this article are included in the article's Creative Commons licence, unless indicated otherwise in a credit line to the material. If material is not included in the article's Creative Commons licence and your intended use is not permitted by statutory regulation or exceeds the permitted use, you will need to obtain permission directly from the copyright holder. To view a copy of this licence, visit http://creativecommons.org/licen ses/by/4.0/.

\section{References}

Abraham, Nicolas, and Maria Torok. 1987. L'Écorce et le Noyau. Paris: Flammarion.

Agamben, Giorgio. 2005a. State of exception (Homo sacer II, 1), trans. K. Attell. Chicago and London: The University of Chicago Press.

Agamben, Giorgio. 2005b. The time that remains. A commentary on the Letter to the Romans, trans. Patricia Dailey. Stanford CA: Stanford University Press.

Agamben, Giorgio. 2012. Opus Dei: Archeologia dell'ufficio: Homo sacer, II, 5. Torino: Bollati Boringhieri.

Agamben, Giorgio. 2013. The highest poverty. Monastic rules and form-of-life, trans. Adam Kotsko. Stanford CA: Stanford University Press.

Agamben, Giorgio. 2014. L'uso dei corpi. Vicenza: Neri Pozza.

Agamben, Giorgio. 2017a. Creazione e anarchia. L'opera nell'età della religione capitalista. Vicenza: Neri Pozza.

Agamben, Giorgio. 2017b. Karman. Breve trattato sull'azione, la colpa e il gesto. Torino: Bollati Bolinghieri.

Agamben, Giorgio. 2019. Creation and anarchy. The work of art and the religion of capitalism, trans. A. Kotsko. Stanford CA: Stanford University Press.

Bindreiter, Uta. 2003. Why Grundnorm? A treatise on the implications of Kelsen's Doctrine. Berlin: Springer.

Burton, Robert. 1927 [1621]. The anatomy of melancholy. New York: Tudor Press.

Cercel, Cosmin. 2018. Towards a jurisprudence of state communism. Law and the failure of the revolution: Abingdon \& New York: Routledge.

Cogan, Mordechai. 1998. Into exile: From the Assyrian conquest of Israel to the fall of Babylon. In The Oxford history of the biblical world, ed. D. Michael, 216-246. New York: Oxford University Press.

Conrad, Edgar W. 1992. Heard but not seen: The representation of 'Books' in the Old Testament. Journal for the Study of the Old Testament 54: 45-59.

Derrida, Jacques. 1994. Force de loi. Le 'Fondement mystique de l'autorité'. Paris: Galilée.

Davies, Philip R. 2005. Josiah and the law book. In Good kings and bad kings, ed. Lester L. Grabbe. New York: T\&T Clark International.

Edelman, Bernard. 2007. Quand les juristes inventent le réel: La fabulation juridique. Paris: Hermann.

Freud, Sigmund. 1957. Mourning and melancholia. In The complete psychological works, trans. J. Strachey, Vol. XIV, 243-258. London: The Hogarth Press and the Institute of Psycho-Analysis.

Goodrich, Peter. 2016. Melancholegalism: Black letter theory and the temporality of law. Crisis \& Critique 3(2): 166-203. Available at https://crisiscritique.org/special09/peter.pdf. Accessed July 29 2020 . 
Goodrich, Peter, and Carlson, David Gray (eds.). 1998. Law and the postmodern mind. Essays on psychoanalysis and jurisprudence. Ann Arbor: The University of Michigan Press.

Henige, David. 2007. Found but not lost: A skeptical note on the document discovered in the temple under Josiah. The Journal of Hebrew Scriptures. https://doi.org/10.5508/jhs.2007.v7.a1. Accessed 22 Sept 2020.

Janzen, David. 2013. The sins of Josiah and Hezekiah: A synchronic reading of the final chapters of Kings. Journal for the Study of the Old Testament. https://doi.org/10.1177/0309089213475396. Accessed 22 Sept 2020.

Kant, Immanuel. 1993. On a supposed right to lie because of philanthropic concerns. Grounding for the metaphysics of morals: With On a supposed right to lie because of philanthropic concerns, trans, 63-67. Hackett: J. Ellington. Indianapolis \& Cambridge.

Kelsen, Hans. 1992. Introduction to the problems of legal theory, trans. B. Litschewski-Paulson, and S. Paulson. Oxford: Oxford University Press.

Kelsen, Hans. 2005. Pure theory of law, trans. M. Knight. Clark NJ: The Lawbook Exchange.

Kings, The Book of. 2017 (edition). According to the Hebrew Bible in English, Jewish Publications Society. https://www.mechon-mamre.org/e/et/et09b23.htm. Accessed 22 Sept 2020.

Klabbers, Jan. 2018. On epistemic universalism and the melancholy of international law. European Journal of International Law 29(4): 1057-1069. https://doi.org/10.1093/ejil/chy073. Accessed 22 Sept 2020.

Klein, Melanie. 1975. Envy and gratitude and other works 1946-1963, ed. M. Masud, and R. Khan. New York: Random House; London: Hogarth Press and the Institute of Psycho-Analysis.

Klibansky, Raymond, Panofsky Erwin, and Saxl Fritz. 1979. Saturn and melancholy: Studies in the history of natural philosophy, religion, and art. Nendeln: Kraus Reprint.

Kripke, Saul A. 1982. Wittgenstein on rules and private language: An elementary exposition. Cambridge, MA: Harvard University Press.

Kristeva, Julia. 1992. Black sun. Depression and melancholia, trans. L.S. Roudiez. New York: Columbia University Press.

Lacan, Jacques. 1975. Le séminaire, livre XX, Encore. Paris: Seuil.

Lacan, Jacques. 1986. Le séminaire, livre VII, L'Éthique de la psychanalyse. Paris: Seuil.

Lacan, Jacques. 1999. Kant avec Sade. In Écrits 2, 243-269. Paris: Seuil.

Murray, Jamie. 2005. Sinthome law: Theoretical constructions upon Lacan's concept of the sinthome. Law \& Critique 16(2): 201-230. https://doi.org/10.1007/s10978-005-4467-y. Accessed 22 Sept 2020.

Noth, Martin. 1960. The history of Israel, trans. P.R. Ackroyd. New York: Harper \& Row.

Radden, Jennifer. 2000. The nature of melancholy: From Aristotle to Kristeva. Oxford: Oxford University Press.

Raz, Joseph. 1974. Kelsen's theory of the basic norm. American Journal of Jurisprudence 19(1): 94-111.

Schmitt, Carl. 1985. Political theology. Four chapters on the concept of sovereignty, trans. G. Schwab. London: The MIT Press.

Silver, Marjorie A. 2011. A transformational melancholy: One law professor's journey through depression. Social Science Research Network. https://doi.org/10.2139/ssrn.1908992. Accessed 22 Sept 2020.

Stott, Katherine. 2005. Finding the lost book of the law: Re-reading the story of 'The Book of the Law' (Deuteronomy-2 Kings) in light of classical literature. Journal for the Study of the Old Testament. https://doi.org/10.1177/0309089205052685. Accessed 22 Sept 2020.

Traverso, Enzo. 2016. Left-wing melancholia: Marxism, history, and memory. New York: Columbia University Press.

Varden, Helga. 2010. Kant and lying to the murderer at the door one more time: Kant's legal philosophy and lies to murderers and Nazis. Journal of Social Philosophy 41(4): 403-421.

Wittgenstein, Ludwig. 1974. Philosophical investigations, trans. G. E. M. Anscombe. Oxford: Basil Blackwell.

Žižek, Slavoj. 2009. The parallax view. London: MIT Press.

Zupančič, Alenka. 2000. Ethics of the real: Kant, Lacan. London: Verso.

Publisher's Note Springer Nature remains neutral with regard to jurisdictional claims in published maps and institutional affiliations. 